\title{
Assessment of the hepatocyte protective effects of gypenoside and its phosphorylated derivative against DHAV-1 infection on duck embryonic hepatocytes
}

Hongxu Du, Jingying Bai, Jinli Wang, Miao He, Wen Xiong, Wenjuan Yuan, Mingyu Qiao, Ke Ming, Yi Wu, Deyun Wang, Yuanliang Hu and Jiaguo Liu* (1)

\begin{abstract}
Background: Duck viral hepatitis $(\mathrm{DVH})$ is an acute disease of young ducklings with no effective veterinary drugs for treatment. Gynostemma pentaphyllum is a well-known traditional Chinese medicine that plays an important role in the treatment of various diseases. Gypenoside (GP), one of the main ingredients of Gynostemma pentaphyllum, was reported with good hepatoprotective effects. However, its low solubility limits its application in the clinics. To improve its solubility and bioactivity, a phosphorylated derivative of gypenoside (pGP) was prepared by the sodium trimetaphosphate-sodium tripolyphosphate (STMP-STPP) method. An infrared spectroscopy method was applied to analyse the structures of GP and pGP. Then, a methyl thiazolyl tetrazolium (MTT) colorimetric assay was applied to study the hepatocyte protective efficacy of these two drugs against duck hepatitis A virus type 1 (DHAV-1) infection, and GPCR, TUNEL labelling and flow cytometry methods were used to study the relevant hepatocyte protective in vitro.
\end{abstract}

Results: The infrared spectroscopy detection results showed that the phosphorylation modification of GP was successful. The MTT colorimetric assay results showed that both GP and pGP possessed good hepatocyte protective efficacy in vitro, and pGP performed better than GP when the drug was added before or after virus inoculation. Furthermore, the qPCR results revealed that both drugs could effectively inhibit the adsorption (when adding GP and pGP pre-virus inoculation), replication and release of DHAV-1, and the viral inhibition rate of PGP was greater than that of GP. The subsequent TUNEL labelling and flow cytometry assays showed that both GP and pGP could significantly inhibit duck embryo hepatocyte apoptosis induced by DHAV-1, and the inhibition effect of PGP was much stronger than that of GP.

Conclusions: GP exerts good hepatocyte protective efficacy not only by inhibiting the proliferation of DHAV-1 but also by inhibiting duck embryonic hepatocyte apoptosis induced by DHAV-1, and phosphorylation modification significantly improves the antiviral and the anti-apoptotic effects of GP. Therefore, pGP has the potential to be developed into a novel drug against DHAV-1 infection.

Keywords: Duck hepatitis a virus type 1, Gypenoside, Phosphorylation modification, Hepatocyte protective effect, Apoptosis

\footnotetext{
* Correspondence: liujiaguo@njau.edu.cn

Institute of Traditional Chinese Veterinary Medicine and MOE Joint

International Research Laboratory of Animal Health and Food Safety, College

of Veterinary Medicine, Nanjing Agricultural University, Nanjing 210095,

People's Republic of China
}

(c) The Author(s). 2019 Open Access This article is distributed under the terms of the Creative Commons Attribution 4.0 International License (http://creativecommons.org/licenses/by/4.0/), which permits unrestricted use, distribution, and reproduction in any medium, provided you give appropriate credit to the original author(s) and the source, provide a link to the Creative Commons license, and indicate if changes were made. The Creative Commons Public Domain Dedication waiver (http://creativecommons.org/publicdomain/zero/1.0/) applies to the data made available in this article, unless otherwise stated. 


\section{Background}

Duck viral hepatitis (DVH) is an acute, contractible, and highly fatal infectious disease of young ducklings characterized primarily by hepatic injury [1]. Originally, the pathogens of this disease mainly include three known types of the duck hepatitis virus (DHV-1, DHV-2, and DHV-3) [2, 3]. Subsequently, DHV-1 has been classified as a member of the new genus Avihepatovirus in the family Picornaviridae and designated Duck hepatitis A virus (DHAV) according to decision of the Virus Taxonomy Ninth Report of the International Committee on Taxonomy of Viruses (ICTV) [4]. DHV-2 and DHV-3 were classified into the family Astroviridae and designated duck astrovirus type I (DAstV-I) and DAstV-II, respectively $[5,6]$. Recently, three serotypes of DHAV have been identified: DHAV-1, the classical serotype (DHV-1); DHAV-2, a type recently isolated in Taiwan; and DHAV-3 [7], a recently described type isolated in South Korea and China [8], based on phylogenetic analysis and crossneutralization tests [7]. Among these types, DHAV-1 is believed to be the most harmful and is distributed worldwide [9]. DHAV-1 mainly endangers young ducklings aged within 3 weeks, with the mortality rate as high as $80 \%$ or even $100 \%$, which seriously jeopardizes the healthy development of the duck industry [10]. Although the clinical applications of an attenuated vaccine can produce a certain effect, there is still immune failure and the risk of reversion of virulence [11]. Moreover, there are no effective drugs available in the clinics so far. Therefore, the development of a new effective drug for the treatment of this disease is particularly urgent.

Traditional Chinese medicine (TCM) has been used for thousands of years and has enabled the successful many viral infectious diseases in China and some other Asian countries [12]. Gynostemma pentaphyllum is a famous TCM. Its main effects are heat-clearing, detoxifying and relieving cough and phlegm [13]. With the development of the chemistry and pharmacology of TCM, an increasing number of effective ingredients are being discovered. For Gynostemma pentaphyllum, modern pharmacology shows that its main bioactive ingredient is gypenoside (GP), which has been revealed to have hepatocyte protective, antiviral, immune-enhancing and antioxidant efficacies [14-17]. The research of Li et al. demonstrated that GP exerted its therapeutic effect on nonalcoholic steatohepatitis by regulating key transcriptional factors and lipogenic enzymes involved in fatty acid oxidation during hepatic lipogenesis [18]. Sornpet et al. also discovered that GP showed significant antiviral activity against the H5N1 virus [19]. Another study found that GP could significantly enhance $\mathrm{T}$ and $\mathrm{B}$ lymphocyte proliferation singly or synergistically with LPS and PHA [15]. However, the unfavourable properties of GP are also rather prominent, such as the low solubility, and the ease of bubble generation and haemolysis, which lowers the bioavailability of GP and its practical applications in the clinics.

To improve the biological activity of TCM ingredients, molecular modification has become an important area of pharmaceutical chemistry research in recent years. At present, the common chemical structure modification methods include sulfation [20, 21], phosphorylation [11, 22], carboxymethylation [23, 24], alkylation [25], acetylation [26], and selenization [27]. Among them, the sulfation and phosphorylation modification methods are the most common in practical applications. However, compared with sulfation modifications, phosphorylation modifications are safer, easier and more environmentally friendly [11, 22, 28]. In addition, our previous studies also found that phosphorylation of a polysaccharide is more efficacious than sulfation at increasing the DVH curative effect [22]. Therefore, in this study, GP was phosphorylated (pGP) to assess its hepatocyte protective effects and the related mechanism was also investigated.

\section{Results}

The infrared spectroscopy characteristics of GP and pGP

The FT-IR spectra of GP and pGP are illustrated in Fig. 1. The specific absorption bands $[29,30]$ of saponins were found both in GP and pGP. The absorption bands at 3600 to $3200 \mathrm{~cm}^{-1}$ were attributed to the phenol hydroxyl stretching vibrations. The peaks at $1652.53 \mathrm{~cm}^{-1}$ and $1383.14 \mathrm{~cm}^{-1}$ were caused by the stretching vibrations of the saponin carbonyl. The absorption bands in the region of 1200 to $950 \mathrm{~cm}^{-1}$ reflected $\mathrm{C}-\mathrm{O}-\mathrm{C}$ and $\mathrm{C}-\mathrm{O}-\mathrm{H}$ stretching vibrations [30]. However, with the modification, pGP had several new absorption peaks in addition to the characteristic absorption peaks of saponins. The absorption peaks at $1293.51 \mathrm{~cm}^{-1}, 994.81 \mathrm{~cm}^{-}$ ${ }^{1}$ and $894.06 \mathrm{~cm}^{-1}$ were caused by the $\mathrm{P}=\mathrm{O}$ stretching vibration, $\mathrm{P}-\mathrm{OH}$ stretching vibration and $\mathrm{P}-\mathrm{O}-\mathrm{C}$ stretching vibration, respectively.

\section{Hepatocyte protective effects of GP and pGP on DEHs GP and $p G P$ added post-virus inoculation}

Table 1 lists the $A_{570}$ values and the hepatocyte protective rates of different concentrations of the two drugs on DEHs infected with DHAV-1 before the drugs were added. The results showed that the hepatocyte protective concentrations of GP ranged from $100 \mu \mathrm{g} / \mathrm{mL}$ to $50 \mu \mathrm{g} /$ $\mathrm{mL}$, and $100 \mu \mathrm{g} / \mathrm{mL}$ showed the most effective protection, with a hepatocyte protective rate of $51.91 \%$. Moreover, all the $A_{570}$ values of the pGP groups were significantly higher than those of the VC group $(p<$ 0.05), and the pGP group exhibited the highest hepatocyte protective rate of $113.42 \%$ at $25 \mu \mathrm{g} / \mathrm{mL}$. Moreover, the hepatocyte protective rates of GP generally increased after the phosphorylation modification. 


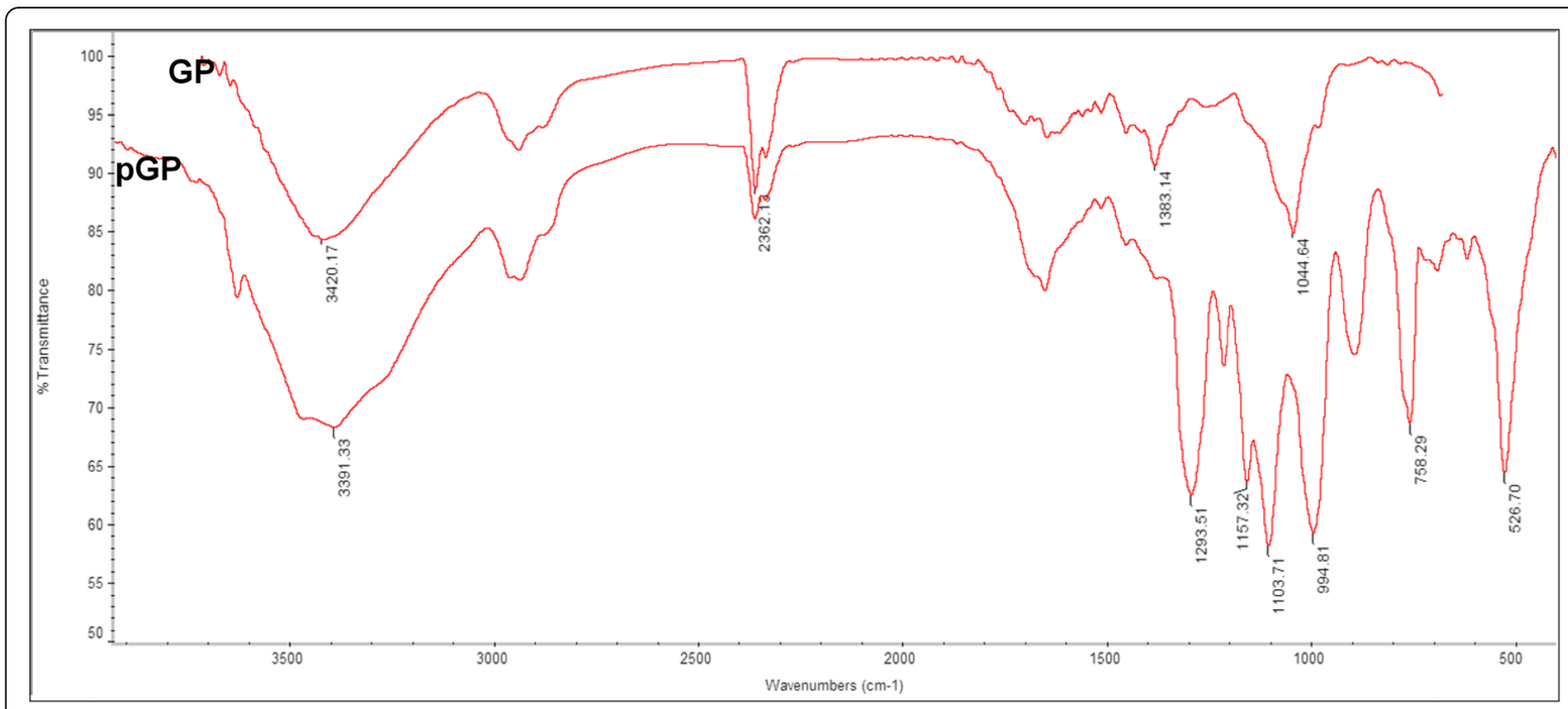

Fig. 1 Infrared spectra of GP and pGP. Not: GP: Gypenoside; pGP: phosphorylated gypenoside

\section{GP and $p G P$ added pre-virus inoculation}

Table 2 shows the $A_{570}$ values and the hepatocyte protective rates of different concentrations of the two drugs on DEHs infected with DHAV-1 after the drugs were added. As listed in the Table 2, the $A_{570}$ values of GP at 50 to $100 \mu \mathrm{g} / \mathrm{mL}$ were significantly higher than those of the VC group $(p<0.05)$. The most effective concentration of GP was $100 \mu \mathrm{g} / \mathrm{mL}$, with a hepatocyte protective rate of $48.17 \%$. The $A_{570}$ values of pGP were also significantly higher than those of the VC group at concentrations of 1.5625 to $25 \mu \mathrm{g} / \mathrm{mL}(p<0.05)$. Moreover, the hepatocyte protective rates of GP generally increased after the phosphorylation modification.

\section{Addition of drug and virus simultaneously}

Table 3 reveals the $A_{570}$ values and the hepatocyte protective rates of the two drugs on the DEHs infected with DHAV-1 when adding the drug and virus at the same time. As shown in the Table 3 , the $A_{570}$ values of GP at concentrations of 12.5 to $100 \mu \mathrm{g} / \mathrm{mL}$ were significantly higher than those of the $\mathrm{VC}$ group $(p<0.05)$, and the most effective concentration of GP was $100 \mu \mathrm{g} / \mathrm{mL}$, with a hepatocyte protective rate of $108.74 \%$. Moreover, the $A_{570}$ values of pGP were significantly higher than that of the $\mathrm{VC}$ group at concentrations ranging from 3.125 to $25 \mu \mathrm{g} / \mathrm{mL}(p<0.05)$, and the pGP group exhibited the highest hepatocyte protective rate of $99.26 \%$ at the concentration of $25 \mu \mathrm{g} / \mathrm{mL}$. Overall, pGP showed a higher hepatocyte protective rate than GP.

\section{Anti-DHAV-1 proliferation assays of GP and pGP in different phases Influence of GP and pGP on DHAV-1 adsorption}

Figure 2 (a) shows the effects of GP and pGP on DHAV-1 adsorption with the post-addition manner of drug addition. There was no DHAV-1 gene expression in the $\mathrm{CC}$ group. In addition, the relative DHAV-1 gene expression levels in the VC, pGP and GP groups were at the same level and showed no significant differences $(p>0.05)$. Figure 2 (b) shows the effects of GP and pGP

Table 1 The $A_{570}$ values of different treatments on DEHs when adding virus firstly $(n=6)$

\begin{tabular}{|c|c|c|c|c|c|}
\hline $\begin{array}{l}\text { GP Concentration } \\
\left(\mu \mathrm{g} \mathrm{mL}^{-1}\right)\end{array}$ & $A_{570}$ & $\begin{array}{l}\text { Hepatocyte } \\
\text { protection rate (\%) }\end{array}$ & $\begin{array}{l}\text { pGP Concentration } \\
\left(\mu \mathrm{gmL}^{-1}\right)\end{array}$ & $A_{570}$ & $\begin{array}{l}\text { Hepatocyte } \\
\text { protection rate (\%) }\end{array}$ \\
\hline 100 & $0.338 \pm 0.009^{b}$ & 51.91 & 25 & $0.523 \pm 0.008^{\mathrm{a}}$ & 113.42 \\
\hline 50 & $0.229 \pm 0.007^{c}$ & 19.94 & 12.5 & $0.486 \pm 0.007^{b}$ & 97.40 \\
\hline 25 & $0.167 \pm 0.010^{d}$ & 1.76 & 6.25 & $0.458 \pm 0.007^{c}$ & 85.28 \\
\hline 12.5 & $0.174 \pm 0.006^{d}$ & 3.81 & 3.125 & $0.380 \pm 0.006^{d}$ & 51.52 \\
\hline o(VC) & $0.161 \pm 0.006^{d}$ & & o(VC) & $0.261 \pm 0.009^{e}$ & \\
\hline $\mathrm{O}(\mathrm{CC})$ & $0.502 \pm 0.003^{a}$ & & $\mathrm{O}(\mathrm{CC})$ & $0.492 \pm 0.008^{\mathrm{a}}$ & \\
\hline
\end{tabular}

a-e Data in same column without same superscript (a-e) differ significantly $(p<0.05)$ GP Gypenoside, $p G P$ phosphorylated gypenoside, VC virus control, CC cell control 
Table $2 A_{570}$ values of different treatments when adding drug firstly $(n=6)$

\begin{tabular}{|c|c|c|c|c|c|}
\hline $\begin{array}{l}\text { GP Concentration } \\
(\mu \mathrm{g} / \mathrm{mL})\end{array}$ & $A_{570}$ & $\begin{array}{l}\text { Hepatocyte } \\
\text { protection rate rate (\%) }\end{array}$ & $\begin{array}{l}\text { pGP Concentration } \\
(\mu \mathrm{g} / \mathrm{mL})\end{array}$ & $A_{570}$ & $\begin{array}{l}\text { Hepatocyte } \\
\text { protection rate rate(\%) }\end{array}$ \\
\hline 100 & $0.351 \pm 0.007^{b}$ & 48.17 & 25 & $0.405 \pm 0.007^{\mathrm{a}}$ & 93.55 \\
\hline 50 & $0.298 \pm 0.007^{c}$ & 20.42 & 12.5 & $0.306 \pm 0.006^{b}$ & 40.32 \\
\hline 25 & $0.274 \pm 0.012^{c d}$ & 7.85 & 6.25 & $0.297 \pm 0.008^{b}$ & 35.48 \\
\hline 12.5 & $0.285 \pm 0.007^{c d}$ & 13.61 & 3.125 & $0.276 \pm 0.009^{c}$ & 24.19 \\
\hline 6.25 & $0.279 \pm 0.011^{c d}$ & 10.47 & 1.5625 & $0.269 \pm 0.006^{c}$ & 20.43 \\
\hline$O(V C)$ & $0.259 \pm 0.012^{d}$ & & $O(V C)$ & $0.231 \pm 0.007^{d}$ & \\
\hline $\mathrm{O}(\mathrm{CC})$ & $0.450 \pm 0.009^{a}$ & & $\mathrm{O}(\mathrm{CC})$ & $0.417 \pm 0.008^{a}$ & \\
\hline
\end{tabular}

${ }^{\mathrm{a}-\mathrm{d}}$ Data in same column without same superscript (a-d) differ significantly $(p<0.05)$ GP Gypenoside, $p G P$ phosphorylated gypenoside, VC virus control, CC cell control

on the DHAV-1 adsorption when the drug was added pre-virus inoculation. As in Fig. 2 (a), no DHAV-1 gene expression was detected in the CC group. Moreover, with the addition of GP and pGP, the relative DHAV-1 gene expression levels in the pGP and GP groups were significantly decreased compared with those in the VC group $(p<0.05)$. In addition, the relative DHAV-1 expression levels of the GP and pGP groups were almost at the same level and had no significant difference between them $(p>0.05)$.

\section{Influences of GP and $p$ GP on DHAV-1 replication}

Figure 2 (c) shows the impacts of GP and pGP on DHAV-1 replication. As shown in Fig. 2 (c), no DHAV-1 gene expression was observed in the $\mathrm{CC}$ group. The relative DHAV-1 gene expression levels of the GP (0.456) and pGP (0.338) groups were obviously lower than those of the VC group $(p<0.05)$. Moreover, the DHAV-1 gene expression level of the pGP group was much lower than that of the GP group $(p<0.05)$.

\section{Influences of GP and pGP on DHAV-1 release}

Figure 2 (d) illustrates the relative DHAV-1 gene expression levels in the CC, VC, GP and pGP groups at the DHAV-1 release phase. As shown in Fig. 2 (d), no
DHAV-1 gene expression was detected in the CC group. Moreover, the relative DHAV-1 gene expression levels in the GP and pGP groups (0.749 and 0.496, respectively) were significantly lower than that of the $\mathrm{VC}$ group $(1.000)(p<0.05)$. Additionally, for the pGP group, the DHAV-1 gene expression level was much lower than in the GP group $(p<0.05)$.

\section{Effects of GP and pGP on DHAV-1-induced cell apoptosis}

To investigate whether DHAV-1 could induce DEH apoptosis and the possible mechanisms of the hepatocyte protective effects of the GP and pGP, we conducted experiments on the normal and infected cells treated in presence or absence of GP and pGP. TUNEL staining is a detection method that can specifically bind to the $3^{\prime}-\mathrm{OH}$ ends of nucleic acids in apoptotic cells. Figure 3 shows the results of TUNEL staining of each group. As shown in Fig. 3, there were a few apoptotic cells (brown florescent dye) in the $\mathrm{CC}$ group. In the $\mathrm{VC}$ group, the apoptotic cell level was greatly elevated compared with that in the CC group. Compared with that in the VC group, the apoptosis-positive cell levels in the GP and pGP groups decreased greatly, and the decrease in the pGP group was more obvious. Moreover, the apoptosis-

Table $3 A_{570}$ values of different treatments when adding drug and virus simultaneously $(n=6)$

\begin{tabular}{llllll}
\hline $\begin{array}{l}\text { GP Concentration } \\
\left(\mu \mathrm{mL}^{-1}\right)\end{array}$ & $A_{570}$ & $\begin{array}{l}\text { Hepatocyte } \\
\text { protection rate rate }(\%)\end{array}$ & $\begin{array}{l}\text { pGP Concentration } \\
\left(\mu \mathrm{mL}^{-1}\right)\end{array}$ & $A_{570}$ & $\begin{array}{l}\text { Hepatocyte protection } \\
\text { rate rate }(\%)\end{array}$ \\
\hline 100 & $0.515 \pm 0.004^{\mathrm{a}}$ & 108.74 & 25 & $0.509 \pm 0.003^{\mathrm{a}}$ & 99.26 \\
50 & $0.425 \pm 0.008^{\mathrm{b}}$ & 59.56 & 12.5 & $0.487 \pm 0.005^{\mathrm{a}}$ & 82.96 \\
25 & $0.374 \pm 0.008^{\mathrm{c}}$ & 31.69 & 6.25 & $0.421 \pm 0.007^{\mathrm{b}}$ & 34.07 \\
12.5 & $0.353 \pm 0.008^{\mathrm{d}}$ & 20.22 & 3.125 & $0.422 \pm 0.010^{\mathrm{b}}$ & 34.81 \\
6.25 & $0.336 \pm 0.008^{\mathrm{de}}$ & 10.93 & 1.563 & $0.401 \pm 0.007^{\mathrm{bc}}$ & 19.26 \\
3.125 & $0.322 \pm 0.007^{\mathrm{e}}$ & 3.28 & 0.781 & $0.396 \pm 0.007^{\mathrm{bc}}$ & 15.56 \\
O(VC) & $0.316 \pm 0.006^{\mathrm{e}}$ & & $0(\mathrm{VC})$ & $0.375 \pm 0.005^{\mathrm{c}}$ & \\
O(CC) & $0.499 \pm 0.005^{\mathrm{a}}$ & & $0(\mathrm{CC})$ & $0.510 \pm 0.005^{\mathrm{a}}$ & \\
\hline
\end{tabular}

a-e Data in same column without same superscript (a-e) differ significantly $(P<0.05)$ GP Gypenoside, $p G P$ phosphorylated gypenoside, VC virus control, $C C$ cell control 


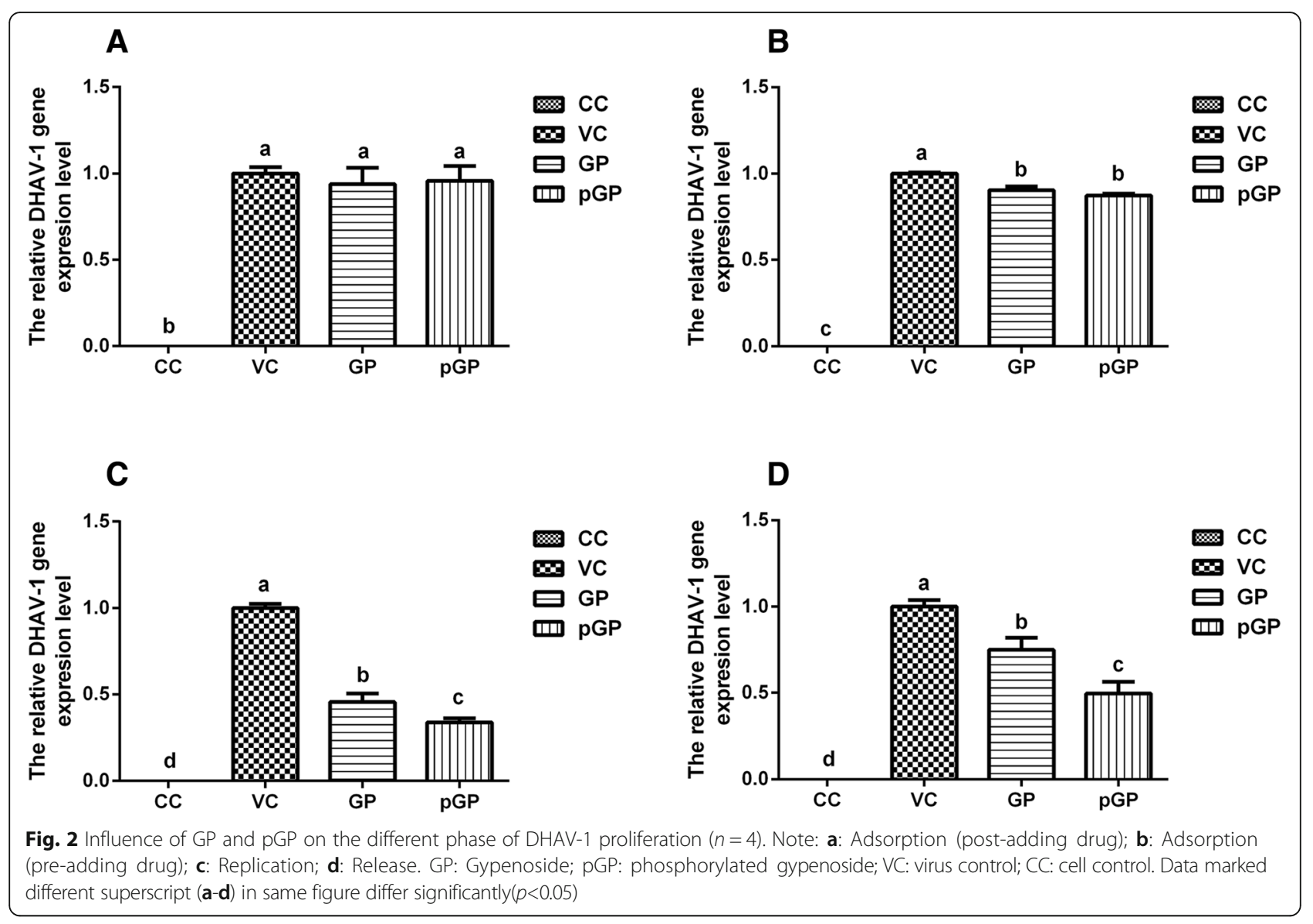

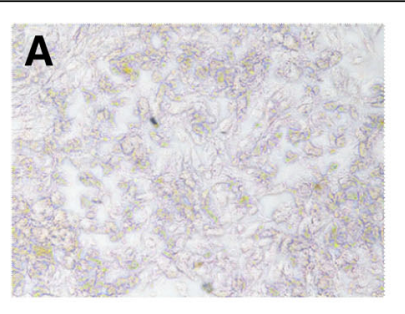
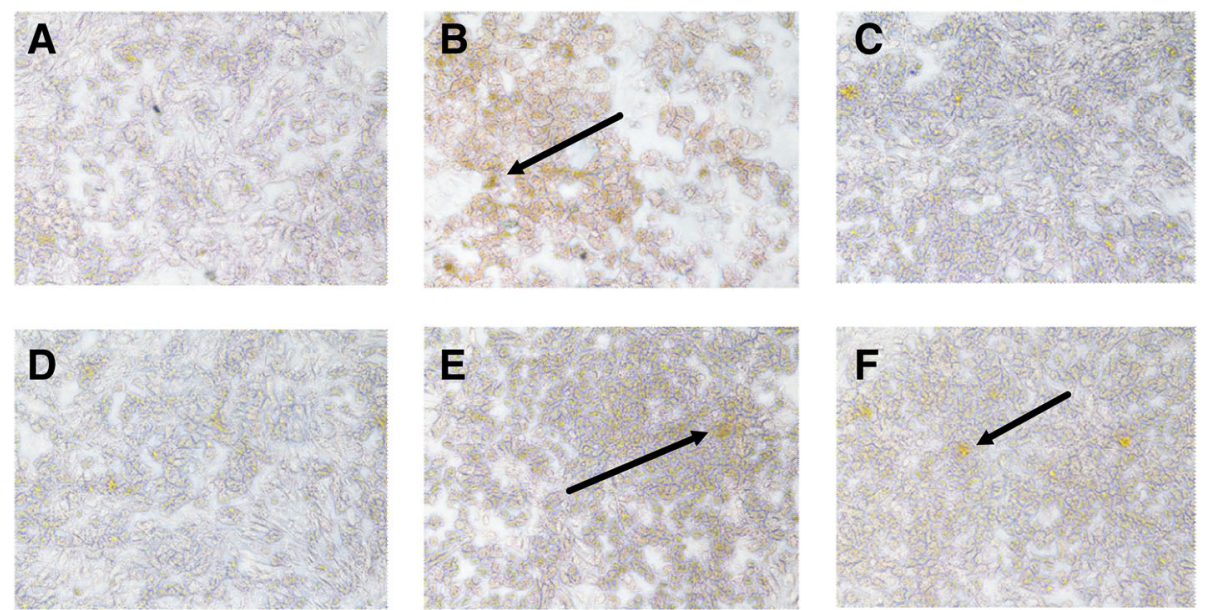

Fig. 3 Changes of apoptotic cell levels in each group analyzed by TUNEL staining. Note: The apoptotic cells are with brown fluorescence. a Cell control group (CC group); b Virus control group (VC group); c Gypenoside control group (GPC group); d Phosphorylated gypenoside control group (pGPC) group; e: Gypenoside group; f: Phosphorylated gypenoside group 
positive cell levels in the GPC and pGPC groups were almost at the same level as that in the CC group.

Subsequently, we randomly selected 5 different fields from each sample and calculated the average brown florescence rate in each group with Image-Pro Plus 6.0. As the results show in Table 4, the average brown florescence rates of CC (11.7\%), GPC (12.81\%) and pGPC $(12.42 \%)$ were at the same level. However, the average brown florescence rate of the $\mathrm{VC}$ group was significantly elevated to $35.89 \%(p<0.05)$. After GP or pGP treatment, the average brown florescence rate of these two groups significantly decreased 17.42 and $20.9 \%$, respectively, which is significantly lower than that of the VC group $(p<0.05)$. Moreover, the average brown florescence rate in the pGP group (14.99\%) decreased significantly $(p<0.05)$ compared with the GP group (18.47\%).

To quantitatively analyse the apoptosis rate of these different groups on DEHs, we conducted experiments on the normal and infected cells treated in the presence or absence of GP and pGP by using flow cytometry. Apoptotic cells were labelled with Annexin V-FITC, and dead cells were stained with PI. The results are presented in Fig. 4. As shown in Fig. 4 (a) and 4 (g), the apoptosis rate in the CC group was rather low, which was the lowest among these groups, and showed no significant difference between the GPC (Fig. 4 (c)) and pGPC (Fig. 4 (d)) groups $(p>0.05)$. In the VC group (Fig. 4 (b)), the apoptosis rate significantly increased to $31.75 \%$, compared with that in the CC group $(p<0.05)$. Interestingly, both GP and pGP could reverse the increasing trend, and the apoptosis rates of the GP (Fig. 4 (e)) and pGP (Fig. 4 (f)) groups were significantly lower (14.70 and $22.67 \%$, respectively) than that in the VC group. Moreover, compared with that of the GP group, the apoptosis rate of the pGP group decreased $7.97 \%$, and the difference was statistically significant $(p<0.05)$.

Table 4 The average brown florescence in each group (\%) $(n=5)$

\begin{tabular}{lll}
\hline Group & $\begin{array}{l}\text { Drug concentration } \\
(\mu \mathrm{g} / \mathrm{mL})\end{array}$ & $\begin{array}{l}\text { Average brown florescence } \\
\text { rate }(\%)\end{array}$ \\
\hline CC & 0 & $11.70 \pm 0.15^{\mathrm{d}}$ \\
VC & 0 & $35.89 \pm 1.07^{\mathrm{a}}$ \\
GPC & 100 & $12.81 \pm 0.25^{\mathrm{d}}$ \\
pGPC & 25 & $12.42 \pm 0.10^{\mathrm{d}}$ \\
GP & 100 & $18.47 \pm 0.21^{\mathrm{b}}$ \\
pGP & 25 & $14.99 \pm 0.43^{\mathrm{c}}$ \\
\hline
\end{tabular}

Note: Data in the same column, marked with different letters indicates a significant difference $(p<0.05)$. CC group Cell control group, VC group Virus control group, GPC group Gypenoside control group, $p G P C$ Phosphorylated gypenoside control group, $E$ Gypenoside group, $F$ Phosphorylated gypenoside group

\section{Discussion}

The use of TCM active ingredients is a recognized shortcut for new drug development. For natural TCM ingredients, low bioactivity is a disadvantage for clinical application. Therefore, appropriate modifications are truly necessary [12]. Chemical modification of TCM ingredients is believed to be one such effective method. At present, phosphorylation of TCM ingredients is considered to be a convenient, safe and environmentally friendly modification method. In addition, our previous studies discovered that the phosphorylation modification of polysaccharides is more efficacious than the sulfation modification at increasing the DVH curative effect [22]. Therefore, in this study, we used the STMP-STPP method to modify GP.

Infrared spectroscopy is an important method to analyse and identify the molecular structure of a substance [31]. After the phosphorylation modification of GP, infrared spectroscopy was used to analyse the chemical structure of GP and its phosphorylated derivative. As the results show in Fig. 1, infrared spectroscopy analysis results showed that the peak patterns before and after the modification of GP were basically the same, indicating that the structures of GP and pGP were similar and the structure of the phosphorylated product did not change substantially. Moreover, both showed the characteristic absorption bands $\left(1652.53 \mathrm{~cm}^{-1}, 32003650\right.$ $\mathrm{cm}^{-1}$ and $2937.62 \mathrm{~cm}^{-1}$ ) of saponins. On the other hand, several new absorption peaks were also found in the pGP spectrum (Fig. 1). Through analysis of these peaks, we found the characteristic absorption peaks of a phosphate ester $\left(1293.51 \mathrm{~cm}^{-1}\right)$, a phosphite ester $\left(994.81 \mathrm{~cm}^{-1}\right)$ and a pyrophosphate $\left(894.06 \mathrm{~cm}^{-1}\right)$. All this evidence suggested that the phosphorylation modification of GP was successful.

After confirming that GP was successfully modified, we wanted to further understand the difference in the hepatocyte protective activities of GP and its phosphorylated derivative. Therefore, the MTT assay, one of the classic methods for detecting cell viability in vitro [32], was applied. The absorbance value at 570 $\mathrm{nm}$ reflects the viability of the cells, and the higher the $A_{570}$ value, the higher the cell viability [33]. As shown in Tables 1-3, the drug and virus were added in three different manners to investigate the hepatocyte protective effects of GP and pGP against DHAV-1 infection. The results showed that both GP and pGP could significantly supress the decrease in cell viability caused by DHAV-1 infection, and pGP possessed better efficacy regardless of the dosing manner. This demonstrated that both GP and pGP could exert hepatocyte protective effects against DHAV-1 infection, and with the phosphorylation modification, GP's efficacy was greatly improved. 

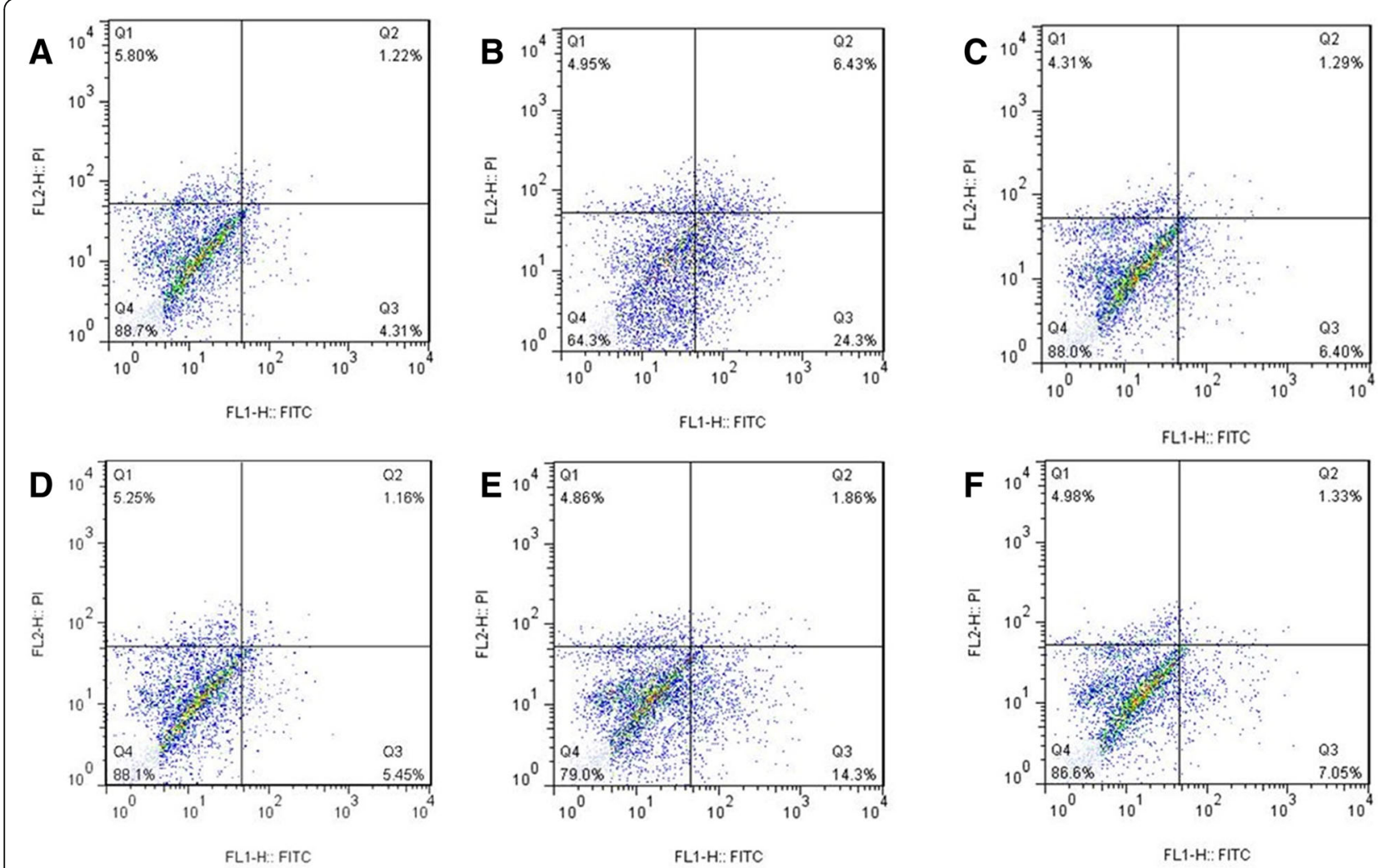

G

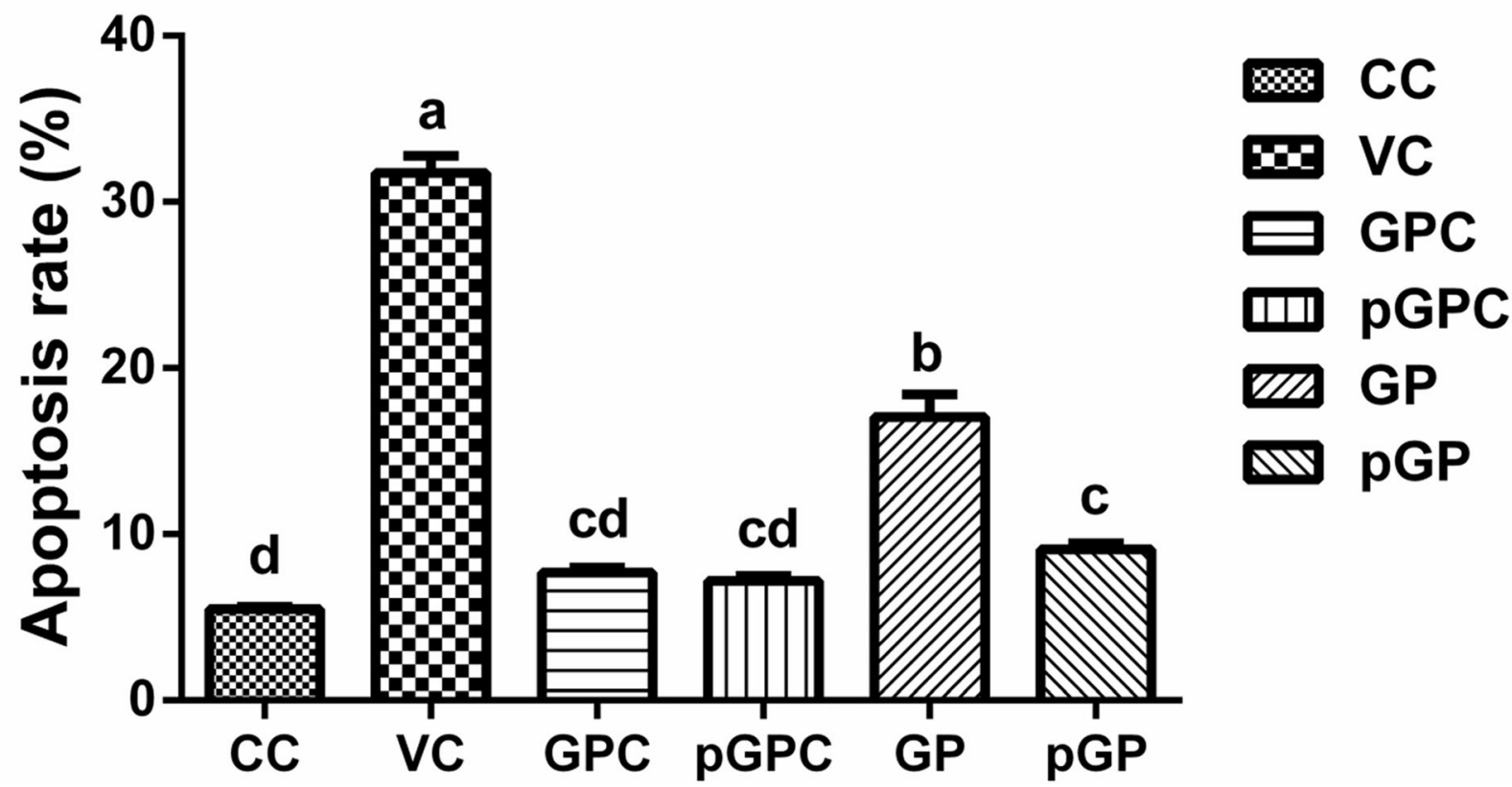

Fig. 4 Flow cytometry detection of the effects of GP and pGP on apoptosis induced by DHAV-1 $(n=3)$. Note: a: Cell control group (CC group); b Virus control group (VC group); c Gypenoside control group (GPC group); d Phosphorylated gypenoside control group (pGPC group); e: GP group; f: pGP group. g: The statistical analysis results of apoptotic rate of each group. Data marked different superscript (a-d) in same figure differ significantly $(p<0.05)$ 
However, what are the mechanisms of their hepatocyte protective effects? To address this question, we investigated the indirect and direct hepatocyte protective effects of these two drugs. For the indirect effect, the above results shown in Tables 1-3 suggest that DHAV-1 infection could significantly impair DEH viability, so the antiviral activity of these two drugs may play an important role in DEH protection. For the direct effect, apoptosis is a well-known type of cell death [34], so the decrease in cell apoptosis may be another mechanism of the DEH protection efficacy of the drugs.

For the indirect hepatocyte protective (antiviral) mechanisms, we know that the proliferation stages of DHAV-1 can be generally divided into three phases: adsorption, replication and release. Therefore, we investigated the influence of GP and pGP on the adsorption phase of DHAV-1 proliferation with two different manners of drug addition. As the results presented in Fig. 2 (a, b), only when adding the drug before virus inoculation are these two drugs able to exert antiviral activity. This may indicate that both GP and pGP may block the adsorption site of DHAV-1 but cannot extricate the adsorbed virus particles. Moreover, the inhibition rates of GP and pGP were on the same level, as shown in Fig. 2 (b). These results may indicate that the blocking site of GP and pGP may be attributed to their related radical group of saponins. Subsequently, the influences of GP and pGP on the two other proliferation phases (replication and release) of DHAV-1 were studied. The results showed that both GP and pGP could inhibit the replication and release of the DHAV-1, and pGP performed better than GP. This demonstrated that the viral replication and release inhibition effects of GP were greatly improved after the phosphorylation modification.

For direct hepatocyte protective (anti-apoptotic) mechanisms, we know that apoptosis is an important type of cell death, and it not only participates in the normal physiological regulation of cells but also participates in the pathological processes of many diseases [34, 35]. Additionally, viral infection-related pathological processes have been reported to be closely related to cell apoptosis, and DHAV-1 is as well. Moreover, several studies have shown that DHAV-1 could induce cell apoptosis not only in vitro but also in vivo [36, 37]. Here, we discovered that DHAV-1 could induce cell apoptosis on DEHs. As illustrated in Fig. 3, the apoptotic cells (with brown florescence) in the VC group were greatly increased compared with those in $\mathrm{CC}$ group. However, the amount of brown florescence in the GP and pGP groups was less than that in the VC group. Combined with the flow cytometry detection results shown in Fig. 4, we can quantitatively review the apoptotic rate in each group. The results shown in Fig. 3 are consistent with the results shown in Fig. 4. Both of these results demonstrate that both GP and pGP could exert hepatocyte protective effects by reducing the DHAV-1-induced apoptosis of DEHs, and the phosphorylation modification of GP elevated the antiapoptotic activity.

\section{Conclusion}

The phosphorylation modification of GP can significantly promote its hepatocyte protective effect against DHAV-1 infection, and pGP is expected to be developed into a new drug to treat DVH induced by DHAV-1.

\section{Methods}

\section{Reagents and virus}

Gypenoside (GP, lot no. ZI20160922, purity $\geq 98 \%$ ) was purchased from Nanjing Zelang Biotechnology Company (Nanjing, China). Sodium trimetaphosphate (STMP, lot no. L1226014) was purchased from Aladdin Company. Sodium tripolyphosphate (STPP, lot no. 201410711) and KBr (lot no. 20151208) were purchased from Sinopharm Group Chemical Reagent Company. Methanol (lot no. 20160410002) was purchased from Tianjin Saifurui Technology Company. The FastPure Cell/Tissue Total RNA Isolation Kit (lot no. 7E270B8), HiScript II Q RT SuperMix for qPCR (+gDNA wiper) kit (lot no. 7E220B8) and ChamQ ${ }^{\text {im }}$ SYBR qPCR Master Mix kit (lot no. 7E152L7) were purchased from Vazyme.

Dulbecco's modified Eagle's medium (DMEM) (Gibco, USA) containing $100 \mathrm{IU} / \mathrm{mL}$ penicillin, $100 \mathrm{IU} / \mathrm{mL}$ streptomycin, and $0.75 \mathrm{mg} / \mathrm{mL}$ glutamine was used, with $10 \%$ fetal bovine serum added as a nutritive medium and with $1 \%$ fetal bovine serum added as maintenance medium (MM). Dulbecco's Hanks balanced salt solution (D-Hank's) was used to wash the cells. Trypsin (Amresco, USA) was diluted to $2 \mathrm{mg} / \mathrm{mL}$ with D-Hank's, and 3-(4,5-dimethylthiazo1-2-yl)-2,5-diphenyltetrazolium bromide (MTT, Amresco, USA) was diluted to $1 \mathrm{mg} / \mathrm{mL}$ with phosphate-buffered saline (PBS, calcium and magnesium-free). DMEM, MM, D-Hank's and MTT were filtered through $0.22 \mu \mathrm{m}$ syringe filters and stored at $4{ }^{\circ} \mathrm{C}$ in brown or dark bottles. All other chemicals used in the experiments were of analytical grade.

Duck fertilized eggs (14-day-old) were purchased from Yangzhou Junhua Breeding Poultry Co., Ltd. The use of duck embryos in this study was approved by the Animal Ethics Committee of Nanjing Agricultural University (approval no. 2012GGC15003). The DHAV-1 ( $L Q_{2}$ strain) used in the experiment was supplied by the Shandong Institute of Poultry in China and was stored at $80^{\circ} \mathrm{C}$. The $\mathrm{TCID}_{50}$ of the virus liquid was $1 \times 10^{-3} / 0.1$ $\mathrm{mL}$, determined by the Reed-Muench assay and diluted to $5 \times 10^{-2}\left(50 \mathrm{TCID}_{50}\right)$ with MM for the following experiments in vitro. 
Preparation of duck embryonic hepatocytes (DEHs)

The DEHs were collected according to a method described previously [38]. Briefly, the eggshell of the 14-day-old fertilized egg was thoroughly disinfected with iodophor, then the chamber end of the eggshell was knocked open with sterile forceps, the eggshell membrane was peeled off and the duck embryo was taken out from the egg. Subsequently, the liver of the duck embryo was collected and digested for 5-6 min with $0.2 \%$ trypsin to obtain DEHs. The seeding density of the DEHs was adjusted to $0.8 \times 10^{6}-1.2 \times 10^{6} / \mathrm{mL}$. Then, the cell plates were placed in a humid atmosphere of $5 \%$ $\mathrm{CO}_{2}$ at $37^{\circ} \mathrm{C}$ for incubation. When the hepatocytes grew as a monolayer, the DEHs could be used for the following study.

\section{Preparation and structural identification of pGP Phosphorylation modification of GP}

pGP was prepared according to the STMP-STPP method described previously [11]. Briefly, $2500 \mathrm{mg}$ of STMP and $1000 \mathrm{mg}$ of STPP were mixed in $50 \mathrm{~mL}$ of double-distilled water with stirring. Thereafter, $150 \mathrm{mg}$ of GP was dissolved in $50 \mathrm{~mL}$ of double-distilled water (by ultrasonication for $30 \mathrm{~min}$ ), and after it was completely dissolved, $50 \mathrm{~mL}$ of phosphorylation reagent was added, and the mixture was stirred in a water bath at a corresponding temperature, $\mathrm{pH}$ and stir time. At the end of the reaction, the solution was concentrated under reduced pressure and evaporated to complete dryness. Then, the dried product was dissolved with $100 \%$ methanol and concentrated and the supernatant was dried, for 3 cycles. Finally, the dried product collected in the previous step was dissolved in the ice water and concentrated and the supernatant was collected and dried. In addition, in order to optimize the preparation process for phosphorylated GP, orthogonal tests were used. The best preparation process was as follows: $4 \mathrm{~h}$ reaction time, 65 ${ }^{\circ} \mathrm{C}$ reaction temperature, $\mathrm{pH} 9$ and 5:2 STMP to STPP reaction ratio. Based on the optimal preparation process above, pGP was obtained. The contents of GP and pGP were determined using the vanillin-glacial acetic acid method [39] and the ascorbic acid method [22, 28], respectively. In addition, the results showed that the content of pGP was $99.67 \%$, which was calculated as the sum of its GP and phosphate contents.

\section{Infrared spectroscopy analysis}

A Fourier transform-infrared (FI-IR) spectroscopy method was used to record the wavenumber range of GP and pGP at $4000-400 \mathrm{~cm}^{-1}$ with a Nicolet 200 Magna-IR spectrometer (Nicolet Instrument Corp). In addition, OMNIC software (Nicolet Instruments Corp.) was used to analyse the major absorption peaks.

\section{Hepatocyte protective effects of GP and pGP against DHAV-1 infection on DEHs}

According to the results of preliminary experiments, the maximum safe concentrations of GP and pGP were $100 \mu \mathrm{g} / \mathrm{mL}$ and $12.5 \mu \mathrm{g} / \mathrm{mL}$, respectively. GP was diluted with MM from 100 to $12.5 \mu \mathrm{g} / \mathrm{mL}$, and pGP was diluted from 25 to $3.125 \mu \mathrm{g} / \mathrm{mL}$. The 96-well plates with DEHs were divided into cell control (CC), virus control (VC), GP and pGP groups, with duplicates of six wells for each group. The virus was diluted with MM, and GP and pGP were added to the culture plate in the following three manners [40-42]. (1) GP and pGP: The virus dilutions were added to the DEH monolayer of each group, with the exception of the CC group, at $100 \mu \mathrm{L}$ per well. After incubation in $5 \% \mathrm{CO}_{2}$ at $37^{\circ} \mathrm{C}$ for $2 \mathrm{~h}$, the virus dilutions were removed, and the plates were washed three times by using D-Hank's. Then, different concentrations of GP and pGP dilutions were added to the DEHs of each group, with the exception of the $\mathrm{CC}$ and $\mathrm{VC}$ groups, at $100 \mu \mathrm{L}$ per well. (2) GP and pGP addition pre-virus inoculation: The different concentrations of GP and pGP dilutions were added to the DEHs of the GP and pGP groups at $100 \mu \mathrm{L}$ per well. After incubation in $5 \% \mathrm{CO}_{2}$ at $37^{\circ} \mathrm{C}$ for $4 \mathrm{~h}$, the drug dilutions were removed, and the plates were washed three times by using D-Hank's. Then, the virus dilutions were added to the DEHs of each group, with the exception of the CC group, at $100 \mu \mathrm{L}$ per well. (3) Addition of drugs and virus simultaneously: DHAV-1 solutions were added to different concentrations of GP and pGP to interact for 2 $\mathrm{h}$ at $4{ }^{\circ} \mathrm{C}$, and the mixed liquids were added to the $\mathrm{DEH}$ monolayer at $100 \mu \mathrm{L}$ per well. The samples prepared with all three manners of drug addition were incubated in a $5 \% \mathrm{CO}_{2}$ atmosphere at $37^{\circ} \mathrm{C}$ for $96 \mathrm{~h}$. Finally, the DEH cell viability was tested by the MTT method. The hepatocyte protective rate was calculated according to the formula [43]: $\left(\bar{A}_{570(\mathrm{drug}+\text { virus })^{-}} \bar{A}_{570(\mathrm{VC})}\right) /\left(\bar{A}_{570(\mathrm{CC})^{-}}\right.$ $\left.\bar{A}_{570(\mathrm{VC})}\right) \times 100 \%$. Based on the $A_{570}$ values and the hepatocyte protective rate, the hepatocyte protective effects of GP and pGP were analysed and compared.

\section{Hepatocyte protective mechanisms of GP and pGP on DEHs Hepatocyte protective effects related to the antiviral mechanisms of GP and $p G P$}

Virus adsorption [22, 38] The 24-well plates with monolayer DEHs were divided into CC, VC, GP and pGP groups, with duplicates of four wells for each group. The virus was diluted with MM. GP and pGP were added to the 24-well plates according to one of the following two manners.

Drugs added post-virus inoculation: $400 \mu \mathrm{L}$ per well of the virus dilutions were added to the monolayer of 
DEHs in each group (except the CC group, which was treated with $400 \mu \mathrm{L}$ of MM per well). After incubation in $5 \% \mathrm{CO}_{2}$ at $37^{\circ} \mathrm{C}$ for $1.5 \mathrm{~h}$, the virus dilutions were removed, and the cells were washed thrice with D-Hank's. Then, $400 \mu \mathrm{L}$ per well of the most effective concentration of the GP and pGP dilutions were added to the corresponding groups. The cells in the $\mathrm{CC}$ and $\mathrm{VC}$ groups were treated with $400 \mu \mathrm{L} \mathrm{MM}$. Then, the supernatant was removed and washed three times with PBS after the cells had been incubated in an atmosphere of $5 \% \mathrm{CO}_{2}$ at $37^{\circ} \mathrm{C}$ for $1.5 \mathrm{~h}$. Almost immediately, $1 \mathrm{~mL}$ of Trizol was added to each well. All samples were stored at $-80^{\circ} \mathrm{C}$ for subsequent qRT-PCR detection.

Drugs added pre-virus inoculation: $400 \mu \mathrm{L}$ per well of the most effective concentration of GP and pGP dilutions were added to the corresponding groups. The cells in the $\mathrm{CC}$ and $\mathrm{VC}$ groups were treated with $400 \mu \mathrm{L}$ of MM. After incubation in an atmosphere of $5 \% \mathrm{CO}_{2}$ at $37^{\circ} \mathrm{C}$ for $6 \mathrm{~h}$, the supernatant was removed, and the cells were washed thrice with D-Hank's. Then, $400 \mu \mathrm{L}$ per well of the virus dilutions were added to the $\mathrm{DEH}$ monolayer of each group (except the CC group, which was treated with $400 \mu \mathrm{L} \mathrm{MM})$. Then, supernatant was removed and washed three times with PBS after the cells had been incubated in a $5 \% \mathrm{CO}_{2}$ atmosphere at $37^{\circ} \mathrm{C}$ for $1.5 \mathrm{~h}$. Almost immediately, $1 \mathrm{~mL}$ of Trizol was added to each well. All samples were stored at $-80^{\circ} \mathrm{C}$ for subsequent qRT-PCR detection.

Virus replication $[\mathbf{2 2}, 38]$ The 24-well plates with the $\mathrm{DEH}$ monolayers were divided into $\mathrm{CC}, \mathrm{VC}, \mathrm{GP}$ and pGP groups, and four wells were duplicated for each group. Next, $400 \mu \mathrm{L}$ per well of the virus dilutions were added into each well (except $\mathrm{CC}$ group, which was treated with $400 \mu \mathrm{L} \mathrm{MM}$ ), and then incubated at $37^{\circ} \mathrm{C}$, $5 \% \mathrm{CO}_{2}$ for $2 \mathrm{~h}$. After the cells were washed three times with D-Hank's, $400 \mu \mathrm{L}$ per well of the most effective concentration of the GP or pGP dilution were added to the DEH monolayer of each group (except the $\mathrm{CC}$ and $\mathrm{VC}$ groups, which were treated with $400 \mu \mathrm{L}$ of $\mathrm{MM}$ ). The cells were incubated at $37^{\circ} \mathrm{C}$ in $5 \% \mathrm{CO}_{2}$ for $12 \mathrm{~h}$. After the cells were washed three times with PBS, $1 \mathrm{~mL}$ of Trizol was added to each well immediately. All samples were stored at $-80^{\circ} \mathrm{C}$ for subsequent qRT-PCR detection.

Virus release $[22,38]$ The 24-well plates with DEH monolayers were divided into $\mathrm{CC}, \mathrm{VC}, \mathrm{GP}$ and pGP groups, and four wells were duplicated for each group. Next, $400 \mu \mathrm{L}$ per well of the virus dilutions were added into each well (except CC group, which was treated with $400 \mu \mathrm{L}$ of MM), and the plate was incubated at $37^{\circ} \mathrm{C}$ in $5 \% \mathrm{CO}_{2}$ for $30 \mathrm{~h}$. Then, the cells were washed thrice with D-Hank's, and $400 \mu \mathrm{L}$ per well of the most effective concentration of GP or pGP was added to the cells of the corresponding groups. Cells in the $\mathrm{CC}$ and $\mathrm{VC}$ groups were treated with $400 \mu \mathrm{L}$ of $\mathrm{MM}$ per well. After the cells were incubated for $2 \mathrm{~h}$ at $37^{\circ} \mathrm{C}$ in a $5 \% \mathrm{CO}_{2}$ incubator, $100 \mu \mathrm{L}$ of the supernatant of each well was collected in a no-enzyme tube and mixed with $100 \mu \mathrm{L}$ of $1.0 \times 10^{6} \mathrm{DEHs}$. Then, $1 \mathrm{~mL}$ of Trizol was added to each tube immediately. All samples were stored at $-80^{\circ} \mathrm{C}$ for subsequent qRT-PCR detection.

\section{qRT-PCR detection of the relative DHAV-1 gene expression level}

Total RNA was extracted from the samples mentioned above with the FastPure Cell/Tissue Total RNA Isolation Kit according to the kit instructions. Then, cDNA was synthetized using a PCR instrument (2720 Thermal Cycler PCR instrument, Applied Biosystems, USA) with the HiScript II Q RT SuperMix for qPCR (+gDNA wiper) Kit. Finally, the semi-quantitative analysis of viral replication was conducted using a real-time PCR instrument (Step One Plus ${ }^{\mathrm{TM}}$ Real Time PCR instrument, Applied Biosystems) with the ChamQ ${ }^{\mathrm{Tm}}$ SYBR qPCR Master Mix Kit. The primers for DHAV- 1 and $\beta$-actin were designed in our previous study. The primer sequences designed in our previous research [43] were as follows: DHAV-1 forward, 5'-GCCACCCTTCCTGAGTTTGT-3'; DHAV-1 reverse, $5^{\prime}$-TACCATTCCACTTCTCCTGCTT-3'; $\beta$-actin forward, 5' -CTTTCTTGGGTATGGAGTCCTG-3'; and $\beta$-actin reverse, $5^{\prime}$-TGATTTTCATCGTGCTGGGT-3'. The reaction parameters were as follows: $95^{\circ} \mathrm{C}$ for $30 \mathrm{~s}$, $95^{\circ} \mathrm{C}$ for $5 \mathrm{~s}$ ( 40 cycles) and $60^{\circ} \mathrm{C}$ for $30 \mathrm{~s}$.

\section{Hepatocyte protective effects related to the anti-apoptotic mechanisms of GP and $p G P$}

Apoptosis analysis by TUNEL staining Six-well plates with monolayer DEHs were divided into $\mathrm{CC}, \mathrm{VC}, \mathrm{GP}$, pGP, GP control (GPC, normal cells treated with GP) and pGP control (pGPC, normal cells treated with pGP) groups, and three wells were duplicated for each group. A total of $1.5 \mathrm{~mL}$ per well of the virus dilution was added to each group (except the CC, GPC and pGP groups, which were treated with $1.5 \mathrm{~mL}$ of $\mathrm{MM}$ ). After incubation in $5 \% \mathrm{CO}_{2}$ at $37^{\circ} \mathrm{C}$ for $2 \mathrm{~h}$, the cells were washed thrice with D-Hank's, and $1.5 \mathrm{~mL}$ per well of the most effective concentration of GP or pGP was added to the respective GP, GPC, PGP or pGPC groups. Meanwhile, cells in the $\mathrm{VC}$ and $\mathrm{CC}$ groups were treated with an equal volume of $\mathrm{MM}$. Then, the plates were incubated in $5 \% \mathrm{CO}_{2}$ at $37^{\circ} \mathrm{C}$ for $24 \mathrm{~h}$, and PBS was used as a washing buffer to wash the cells three times. After the cells were fixed by using $4 \%$ paraformaldehyde for 30 min, TUNEL staining was performed according to the 
instructions, and the cells were visualized by an inverted fluorescence microscope.

Apoptosis analysis by flow cytometry In this experiment, cells were cultured in 6-well plates. The cell grouping and treating processes were the same as in section 2.5.2.1. After the plates were incubated for $24 \mathrm{~h}$ at $37^{\circ} \mathrm{C}$ in a $5 \% \mathrm{CO}_{2}$ incubator, the supernatants were collected in $1.5 \mathrm{~mL}$ EP tubes and centrifuged for $5 \mathrm{~min}$ at $300 \times$ g. The resulting supernatant was removed, and the cell pellets were collected. In addition, $1 \mathrm{mg} / \mathrm{mL}$ collagenase was added to each well of the 6-well plates to digest the DEH monolayer for $30 \mathrm{~min}$ at $37^{\circ} \mathrm{C}$ in a $5 \% \mathrm{CO}_{2}$ incubator. Then, the digested cells were blown off gently using disposable plastic pipettes, and the digested cells were collected in $1.5 \mathrm{~mL}$ EP tubes and centrifuged at $300 \times \mathrm{g}$ for $4 \mathrm{~min}$. The cell pellets were merged together, washed twice with PBS, and centrifuged at $300 \times \mathrm{g}$ for 5 $\mathrm{min}$, and the supernatants were discarded. Then, the rest of the experimental steps were performed strictly in accordance with the instructions, and the samples were detected by flow cytometry (FACSCalibur, BD).

\section{Statistical analysis}

The relative gene expression levels were analysed with the $2^{-\triangle \Delta C T}$ method [44]. All data were subjected to Duncan's multiple range test by using SPSS 20.0 software and expressed as the mean \pm S.E. Significant differences were considered $p<0.05$.

\section{Abbreviations}

CC: Cell control; DAstV-I: Duck astrovirus type I; DAstV-II: Duck astrovirus type II; DEHs: Duck embryonic hepatocytes; D-Hank's: Dulbecco's Hanks balanced salt solution; DHAV-1: Duck hepatitis A virus type 1; DHV-1: Duck hepatitis virus type 1; DMEM: Dulbecco's modified Eagle's medium; DVH: Duck vira hepatitis; FI-IR: Fourier transform-infrared; GP: Gypenoside; GPC: Gypenoside control; ICTV: International Committee on Taxonomy of Viruses; MM: Maintenance medium; MTT: Methyl thiazolyl tetrazolium; PBS: Phosphate-buffered saline; pGP: Phosphorylated derivative of gypenoside; PGPC: Phosphorylated derivative of gypenoside control; STMP-STPP: Sodium trimetaphosphate-sodium tripolyphosphate; TCM: Traditional Chinese medicine; TUNEL: TdT-mediated dUTP Nick-End Labelling; VC: Virus control

\section{Acknowledgements}

We appreciate all the staff at the Institute of Traditional Chinese Veterinary Medicine of Nanjing Agricultural University for their experimental assistance.

\section{Funding}

This project was funded by the National Natural Science Foundation of China (Grant No. 31572557, 31772784), the Fundamental research funds for the central universities (Y0201700441, KYYJ201803), the Project Funded by the Priority Academic Program Development of Jiangsu Higher Education Institutions (PAPD), and the Special Fund for Agro-Scientific Research in the Public Interest (201303040 and 201403051). The funding body had no role in the design of the study, the collection, analysis, and interpretation of data, or the writing of the manuscript.

\section{Availability of data and materials}

The datasets used and/or analysed during the current study are available from the corresponding author upon reasonable request.

\section{Authors' contributions}

Conceived and designed the experiments: JL. Performed the experiments: $H D$, JB, JW, MH, WX, WY, MQ, KM, YW, DW, and YH. Analysed the data: JB, JW, MH. Wrote the paper: HD and JB. All authors have read and approved the final manuscript.

\section{Ethics approval}

This study was approved by the Animal Ethics Committee of Nanjing Agricultural University (approval no. 2012GGC15003).

\section{Consent for publication}

Not applicable.

\section{Competing interests}

The authors declare that they have no competing interests.

\section{Publisher's Note}

Springer Nature remains neutral with regard to jurisdictional claims in published maps and institutional affiliations.

Received: 13 June 2018 Accepted: 29 April 2019

Published online: 07 May 2019

References

1. Levine PP, Fabricant J. A hitherto-undescribed virus disease of ducks in North America. CORNELL VET. 1950;40(1):71-86.

2. Toth TE. Studies of an agent causing mortality among ducklings immune to duck virus hepatitis. Avian Dis. 1969;13(4):834-46.

3. Haider SA, Calnek BW. In vitro isolation, propagation, and characterization of duck hepatitis virus type III. Avian Dis. 1979;23(3):715

4. Tseng $\mathrm{CH}$, Knowles NJ, Tsai HJ. Molecular analysis of duck hepatitis virus type 1 indicates that it should be assigned to a new genus. Virus Res. 2007; 123(2):190-203.

5. Todd D, Smyth VJ, Ball NW, Donnelly BM, Wylie M, Knowles NJ, Adair BM. Identification of chicken enterovirus-like viruses, duck hepatitis virus type 2 and duck hepatitis virus type 3 as astroviruses. AVIAN PATHOL. 2009;38(1):21-9.

6. Wang $X$, Wang $Y$, Xie $X$, Zhang B, Zhang D. Expression of the C-terminal ORF2 protein of duck astrovirus for application in a serological test. J Virol Methods. 2011;171(1):8-12

7. Tseng $\mathrm{CH}$, Tsai HJ. Molecular characterization of a new serotype of duck hepatitis virus. Virus Res. 2007;126(1-2):19-31.

8. Kim MC, Kwon YK, Joh SJ, Kim SJ, Tolf C, Kim JH, Sung HW, Lindberg AM, Kwon JH. Recent Korean isolates of duck hepatitis virus reveal the presence of a new geno- and serotype when compared to duck hepatitis virus type 1 type strains. Arch Virol. 2007;152(11):2059-72.

9. Yugo DM, Hauck R, Shivaprasad HL, Meng XJ. Hepatitis virus infections in poultry. Avian Dis. 2016;60(3):576.

10. Shen $Y$, Cheng A, Wang $M$, Chen $S$, Jia R, Zhu D, Liu M, Sun $K$, Yang $Q$ Chen X. Development of an indirect ELISA method based on the VP3 protein of duck hepatitis a virus type 1 (DHAV-1) for dual detection of DHAV-1 and DHAV-3 antibodies. J Virol Methods. 2015;225:30-4.

11. Wen X, Yun C, Yu W, Liu J. Roles of the antioxidant properties of icariin and its phosphorylated derivative in the protection against duck virus hepatitis. BMC Vet Res. 2014;10(1):226.

12. Tang JL, Liu BY, Ma KW. Traditional Chinese medicine. LANCET. 2008; 372(9654):1938-40.

13. Alhasani RH, Biswas L, Tohari AM, Zhou X, Reilly J, He JF, Shu X. Gypenosides protect retinal pigment epithelium cells from oxidative stress. FOOD CHEM TOXICAL. 2018:112:76-85.

14. Wang P, Niu L, Gao L, Li WX, Jia D, Wang XL, Gao GD. Neuroprotective effect of gypenosides against oxidative injury in the substantia nigra of a mouse model of Parkinson's disease. J INT MED RES. 2010;38(3):1084-92.

15. Yu Y, Lu Y, Bo R, Huang Y, Hu Y, Liu J, Wu Y, Tao Y, Wang D. The preparation of gypenosides liposomes and its effects on the peritoneal macrophages function in vitro. Int J Pharm. 2014;460(1-2):248-54.

16. Zhao J, Ming Y, Wan Q, Shaojun YE, Xie S, Zhu YI, Wang Y, Zhong Z, Ling LI, Qifa YE. Gypenoside attenuates hepatic ischemia/reperfusion injury in mice via anti-oxidative and anti-apoptotic bioactivities. EXP THER MED. 2014;7(5): 1388-92.

17. Yu H, Guan Q, Guo L, Zhang H, Pang X, Cheng Y, Zhang X, Sun Y. Gypenosides alleviate myocardial ischemia-reperfusion injury via attenuation of oxidative 
stress and preservation of mitochondrial function in rat heart. CELL STRESS CHAPERON. 2016;21(3):1-9.

18. Li H, Ying $H, H u A, H u$ Y, Li D. Therapeutic effect of Gypenosides on nonalcoholic steatohepatitis via regulating hepatic lipogenesis and fatty acid oxidation. Biol Pharm Bull. 2017:40(5):650.

19. Sornpet B, Potha T, Tragoolpua Y, Pringproa K. Antiviral activity of five Asian medicinal pant crude extracts against highly pathogenic H5N1 avian influenza virus is. Asian Pac J Trop Med. 2017;10(9):871-6.

20. Chen Y, Xiong W, Zeng L, Wang D, Liu J, Wu Y, Hu Y. Comparison of bush Sophora root polysaccharide and its sulfate's anti-duck hepatitis a virus activity and mechanism. CARBOHYD POLYM. 2014;102(1):333-40.

21. Xie JH, Wang ZJ, Shen MY, Nie SP, Gong B, Li HS, Zhao Q, Li WJ, Xie MY. Sulfated modification, characterization and antioxidant activities of polysaccharide from Cyclocarya paliurus. FOOD HYDROCOLLOID. 2016; 53:7-15.

22. Wang Y, Chen Y, Du H, Yang J, Ming K, Song M, Liu J. Comparison of the anti-duck hepatitis a virus activities of phosphorylated and sulfated Astragalus polysaccharides. EXP BIOL MED. 2016;242(3):344.

23. Pal S, Sen G, Mishra S, Dey RK, Jha U. Carboxymethyl tamarind: synthesis, characterization and its application as novel drug-delivery agent. J Appl Polym Sci. 2008:110(1):392-400

24. Pal S. Carboxymethyl guar: its synthesis and macromolecular characterization. J Appl Polym Sci. 2009;111(5):2630-6.

25. Rosa S: Process for preparing alkylated polysaccharide binding agents. In: US; 1965.

26. Qi H, Zhang QT, Hu R, Zhang K, Li Z. In vitro antioxidant activity of acetylated and benzoylated derivatives of polysaccharide extracted from Ulva pertusa (Chlorophyta). Bioorg Med Chem Lett. 2006;16(9):2441-5.

27. Zhang Z, Zhang Q, Wang J, Shi X, Song H, Zhang J. In vitro antioxidant activities of acetylated, phosphorylated and benzoylated derivatives of porphyran extracted from Porphyra haitanensis. CARBOHYD POLYM. 2009; 78(3):449-53.

28. Xiong W, Ma X, Wu Y, Chen Y, Zeng L, Liu J, Sun W, Wang D, Hu Y. Determine the structure of phosphorylated modification of icariin and its antiviral activity against duck hepatitis virus a. BMC Vet Res. 2015;11(1):1-9.

29. Li Y, Shao W, Dong R, Jiang J, Diao S. Prediction of saponin content in soapnut ( Sapindus mukorossi Gaertn.) fruits by near infrared spectroscopy. J NEAR INFRARED SPEC. 2018:26(2):95-100.

30. Almutairi MS, Ali M. Direct detection of saponins in crude extracts of soapnuts by FTIR. Nat Prod Res. 2015;29(13):1271-5.

31. Barth A. Infrared spectroscopy of proteins. Biochim Biophys Acta. 2007; 1767(9):1073.

32. Wang $H$, Wang F, Tao X, Cheng H. Ammonia-containing dimethyl sulfoxide: an improved solvent for the dissolution of formazan crystals in the 3-(4,5dimethylthiazol-2-yl)-2,5-diphenyl tetrazolium bromide (MTT) assay. Anal Biochem. 2012;421(1):324-6.

33. Fan $Y$, Liu J, Wang D, Song $X$, Hu Y, Zhang C, Zhao X, Nguyen TL. The preparation optimization and immune effect of epimedium polysaccharidepropolis flavone liposome. CARBOHYD POLYM. 2013:94(1):24.

34. Thompson CB. Apoptosis in the pathogenesis and treatment of disease. SCIENCE. 1995;267(5203):1456-62.

35. Hengartner MO. The biochemistry of apoptosis. NATURE. 2000;407(6805): 770.

36. Cao J, Ou X, Zhu D, Ma G, Cheng A, Wang M, Chen S, Jia R, Liu M, Sun K. The 2A2 protein of duck hepatitis a virus type 1 induces apoptosis in primary cell culture. Virus Genes. 2016;52(6):780-8

37. Sheng XD, Zhang WP, Zhang QR, Gu CQ, Hu XY, Cheng GF. Apoptosis induction in duck tissues during duck hepatitis a virus type 1 infection. Poult Sci. 2014;93(3):527-34.

38. Yao F, Chen Y, Shi J, Ming K, Liu J, Xiong W, Song M, Du H, Wang Y, Zhang S. Replication cycle of duck hepatitis a virus type 1 in duck embryonic hepatocytes. VIROLOGY. 2016:491:73-8.

39. Lowry OH, Roberts NR, Leiner KY, MI WU, Farr AL. The quantitative histochemistry of brain. I. Chemical methods. J Biol Chem. 1954:207(1):1-17.

40. Zhao X, Hu Y, Wang D, Guo L, Yang S, Fan Y, Zhao B, Wang Y, Abula S. Optimization of sulfated modification conditions of tremella polysaccharide and effects of modifiers on cellular infectivity of NDV. Int J Biol Macromol. 2011:49(1):44-9.

41. Yu L, Wang D, Hu Y, Huang X, Wang J. Sulfated modification of epimedium polysaccharide and effects of the modifiers on cellular infectivity of IBDV. CARBOHYD POLYM. 2008;71(2):180-6.
42. Zhang J, Hu Y, Wang D, Qin T, Liu C, Liu X, Sheng X, Chang S, Fan Y, Guo L. The optimization of sulfation modification conditions for ophiopogonpolysaccharide based on antiviral activity. Int J Biol Macromol. 2012;51(4):657-62.

43. Du H, Zhang S, Song M, Wang $Y$, Zeng $L$, Chen $Y$, Xiong W, Yang J, Yao F, Wu Y. Assessment of a flavone-polysaccharide based prescription for treating duck virus hepatitis. PLoS One. 2016;11(1):e146046.

44. Schmittgen TD. Analysis of relative gene expression data using real-time quantitative PCR and the 2(-Delta Delta C(T)) method. METHODS. 2001; 25(4):402-8.

\section{Ready to submit your research? Choose BMC and benefit from:}

- fast, convenient online submission

- thorough peer review by experienced researchers in your field

- rapid publication on acceptance

- support for research data, including large and complex data types

- gold Open Access which fosters wider collaboration and increased citations

- maximum visibility for your research: over $100 \mathrm{M}$ website views per year

At $\mathrm{BMC}$, research is always in progress.

Learn more biomedcentral.com/submissions 